\title{
USING SOCIAL MEDIA DATA TO PLAN FOR TOURISM
}

\author{
Alina Zajadacz 무, Aleksandra Minkwitz 무 \\ Department of Tourism and Recreation, Adam Mickiewicz University in Poznań, Poland
}

Manuscript received: June 17, 2020

Revised version: September 9, 2020

\begin{abstract}
Zajadacz A., Minkwitz A., 2020. Using social media data to plan for tourism. Quaestiones Geographicae 39(3), Bogucki Wydawnictwo Naukowe, Poznań, pp. 125-138. 1 fig, 2 tables.

ABSTRACT: The purpose of the article is to present the concept of using social media (SM) as data sources and communication tools, useful at the various stages of planning, implementing and monitoring the effects of tourism development on a local level. The first part discusses the stages of planning, then presents the characteristics of SM, along with a discussion of the issues presented in the literature to this date. The next part presents data sources and methods of research on SM and functions that they can perform in tourism. The concept presented, on the one hand, reviews the perspectives of practical use of SM as a communication tool and source of data and, on the other hand, the challenges related to the need to further deepen research on tourism planning methods that are adequate to the continuously changing environment.
\end{abstract}

KEY WORDS: social media, tourism planning, user-generated content (UGC)

Corresponding author: Aleksandra Minkwitz, alemin1@amu.edu.pl

\section{Introduction}

Dynamic development and increasing competitiveness among tourist destinations have been observed for many years (UNWTO 2017). Activities aimed at creating tourism development plans in such a turbulent and chaotic environment (Phillips, Moutinho 2014) require a strategic (well-thought-out and structured) approach, adequate to changing conditions (Liu et al. 2008), allowing agile response both at the stage of creating plans and during their implementation. Of fundamental importance in this process is to respect the principles of sustainable development, especially in very popular tourist destinations, struggling with problems referred to as overtourism. The accuracy of the formulation of action scenarios in tourism development plans and strategies depends largely on the reliability of the prepared diagnosis, allowing the identification of, among others, possibilities and limitations of tourism development in a given area. This stage requires a large data bank describing the complex tourism system. Currently, a lot of data including tourist attractions, tourist traffic or tourists' opinions about visited places is generated in such a popular medium as the Internet by users (user-generated content - UGC) of many types of social media (SM). The transformation of a significant part of Internet activity by society resulted in the creation of a completely new dimension in tourism management (Tavakoli, Wijesinghe 2019). UGC continuously provide vast amounts of data, easily available anywhere, anytime (Guo et al. 2017). However, this data is dispersed and relatively difficult to synthesise. Therefore, it can be assumed that currently SM in the context of data sources or tools useful in the process of planning tourism development provide new opportunities (in access to data, communication tools) as well 
as create many methodical challenges (Dinis et al. 2019, Sigala et al. 2019). As Sigala et al. (2019) point out the topic of using data generated in SM in the process of planning tourism development is poorly understood. So far, many studies have examined how big data is transforming for-profit firms (Günther et al. 2017). Limited research has so far pointed out the use and impact of big data on the management and the work of governmental, nonprofit organisations (Kim et al. 2014, Lavertu 2016) such as economic development agencies or Destination Management Organisation (DMO) preparing tourism development plans at various spatial scales. This knowledge gap is important given the functions that these agencies and organisations perform. They do not only support individual economic factors, but can also primarily alter the wider economies and societies in which they operate, e.g. by improving well-being, growing employment, supporting sustainability and liveability (Sigala et al. 2019).

\section{Aims, methods and data sources}

The aim of the article is to present the concept of using SM as data sources and communication tools, useful at particular stages of planning tourism development on a local level, based on a review of literature relating to SM in tourism. The first part discusses the basic stages of the tourism development planning and the characteristics of $\mathrm{SM}$. Based on a review of the literature, an attempt was made to answer the following questions:

1. $Q_{1}$ - what research problems exist in regards to $\mathrm{SM}$ as a tourism-planning tool?

2. $\mathrm{Q}_{2}$ - what are the possibilities and limitations of the use of SM as a data bank and social communication tools at various stages of tourism planning on a local scale?

Table 1. Numbers of journal articles by journal.

\begin{tabular}{|l|c|}
\hline \multicolumn{1}{|c|}{ Journal title } & $\begin{array}{c}\text { Article } \\
\text { number }\end{array}$ \\
\hline Annals of Tourism Research & 37 \\
\hline $\begin{array}{l}\text { Journal of Hospitality and Tourism Manage- } \\
\text { ment }\end{array}$ & 18 \\
\hline $\begin{array}{l}\text { Journal of Hospitality, Leisure, Sport and } \\
\text { Tourism Education }\end{array}$ & 5 \\
\hline Journal of Outdoor Recreation and Tourism & 4 \\
\hline Tourism Management & 145 \\
\hline Tourism Management Perspectives & 32 \\
\hline
\end{tabular}

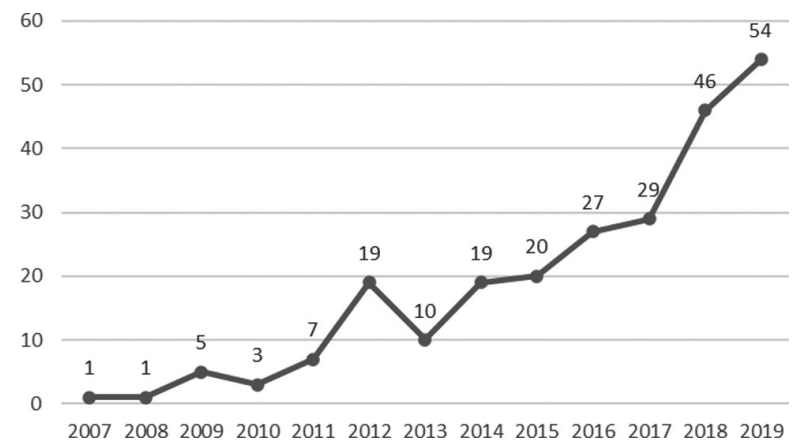

Fig. 1. Publication numbers by year.

The review was made using bibliometric analysis. Searches were performed in the Science Direct database among titles, keywords and abstracts. We used keywords (often found in publications in the field of SM and tourism): social media, online reviews, yelp, web 2.0, new media, user-generated content, tourism 2.0, TripAdvisor, Facebook, eWOM. We collected 241 articles from the year 2006 to 2019 published in six journals recognised as opinion forming for research in the field of tourism (Table 1).

Publications of SM-related research in tourism have a relatively short history. The first publications were in 2007 and the number was growing in the analysed period (Fig. 1). From 2007 to 2011 there were a few publications. After 2012 there was rapid growth, resulting in 196 articles from the 213 collected. In 2019, there were 54 publications.

\section{The planning process of tourism development}

Contemporary concepts of tourism planning, based on sustainable development, assume an important role of social consultations, taking into account, in particular, the opinions of tourists, residents, entrepreneurs and institutions involved in the tourism development process (Zajadacz 2017). The planning process is a cycle based on the diagnosis of conditions for tourism development, formulation of strategic goals, selection of optimal development scenarios and their implementation and evaluation of the achieved effects. Fletcher (2005) distinguishes nine stages of planning, which are:

1. the initial stage, preparation of tests,

2. setting strategy goals, 
3. review of secondary data,

4. collection of primary data,

5. secondary and primary data analysis,

6. policy initiation, formulation of an action plan,

7. recommendations,

8. implementation, and

9. monitoring, evaluation and verification of activities.

The preliminary stage consists of determining the place of tourism among development priorities and includes consultations with local communities, authorities and enterprises. The effect is to establish the attitude of the entities to the development of the tourism function and to determine whether there is a need to create a strategy for its development. Setting the strategy's goals includes determining the effects to be achieved through the development of tourism (Tribe 2016). The goal should be accompanied by building and implementing strategies at later stages of planning. For example, the goal may be to increase employment or develop luxury tourism, dedicated to people with high incomes. The set goals should be measurable and cannot be contradictory.

An overview of existing data allows systematising the current state of knowledge. Its implementation is crucial because it prevents duplication of data, which can generate additional unnecessary costs and time. As a secondary data bank, SM generated data is increasingly used to assess tourism potential. An example of this type of research related to one aspect of the tourist potential, which is the image of the place, are the studies conducted by McCreary et al. (2019). Their authors, based on photo analysis, with regard to the universality of the method used, stated that the study demonstrates the feasibility of qualitatively utilising SM data as a rather rapid and lowcost process to determine the key components of specific visitors' destination image (McCreary et al. 2019). In addition, other authors emphasise the usefulness of photography analysis in SM. As stated by Richards and Friess (2015), SM data, particularly geo-tagged photographs, are spatially explicit and contain visual information that can be used to infer cultural use. Similarly, Sonter et al. (2016) found a significant and positive relationship between photos uploaded to the SM site Flickr and survey visitation rates in relation to conserved lands. Combining georeferenced photos volunteered by SM users with view shed analysis presents a unique opportunity to evaluate the landscape qualities and visible attributes associated with high valued areas (Yoshimura, Hiura 2017, Van Berkel et al. 2018). Also Wood et al. (2013) conclude that the crowd-sourced information (big data from Flickr) can indeed serve as a reliable proxy for empirical visitation rates. This new approach offers opportunities to understand which elements of nature attract people to locations around the globe and whether changes in ecosystems will alter visitation rates.

The phase associated with the collection of primary data includes the supplementation of information gaps created after the review of primary data (Jennings 2010). Research may concern such issues as the characteristics of tourist traffic, accommodations, tourist attractions or education and training needs. The created data bank should be characterised by the complexity and continuity of data collection. This results in the necessity for the constancy of the collection and storage methodology, as well as continuous development allowing for the inclusion of new sources as they arise. The data analysis is the basis for determining the tourism potential of the destination and includes four basic issues: asset assessment, tourist market analysis, development planning and analysis of the impact of the plan implementation on the destination status. The scope of analyses should include both quantitative and qualitative research.

Formulating the policy and action plan includes creating alternative development strategies. The individual options are then evaluated in terms of costs, economic, environmental and socio-cultural benefits as well as problem areas. The selected plan is prepared to the full extent and forms the basis for the formulation of the operating policy. The recommendation stage is a period of dialogue between the authorities and experts in the field of tourism. Discussions select noteworthy issues, and those of minor importance are eliminated. This leads to the final shape of the development plan. During the implementation phase, special attention should be paid to the gradual introduction of the plan and the observation of phenomena that may be a cause for concern. It is also important to use methods that allow public debate on implemented changes. Monitoring, evaluation and verification of 
activities are used to detect any deviations from the planned development path. It is important here to assess the impact of the exceptions that exist on the implementation of the plan. Planning teams should monitor all internal and external factors and react if necessary, creating recommendations for entities implementing the plan.

The whole process of planning and implementing the adopted strategy implies information needs. These data is necessary in order to (Sigala et al. 2019):

1. justify the expenditure of scarce public sector resources by local governments, or indeed any tier of government,

2. provide an evidence base on progress towards economic development goals,

3. help local government agents to better allocate funds across economic development plans by monitoring and evaluating their impact and return on investment,

4. assist in the management of economic development funds by assisting local governments to monitor their performance and impact and take appropriate corrective actions,

5. assist economic development practitioners to select the most appropriate and effective strategies in order to achieve their economic development goals, and

6. build momentum in economic development efforts by creating knowledge of local success that can be shared with businesses, the community and other key stakeholders.

The results of research carried out by McCreary et al. (2019) demonstrate how a qualitative analysis of SM data that reveal visitors' destination image can be used to enhance destination planning and marketing. In turn, Yung et al. (2003) found that place names can be a successful place to start conversations regarding the political meanings of place. Extending this same logic, planners can capitalise on the power of images in place-based management (Allen et al. 2009, EPA 2020) by displaying visitor-derived images of a place to elicit conversation during public planning processes in tourism destinations. McCreary et al. (2019) suggest that tourism providers to monitor changes in destination image and visitors' relationships with the destination can use UGC. With data that are consistently geo-tagged, destination managers may also track spatial patterns of visitor movements and destination images over time.
The main problems faced by planner teams are, first, the collection and analysis of a data bank (especially at the stage of diagnosis) and, second, the lack of tools enabling efficient public consultations of a wide range. Both in the first and the second cases, Internet sources gain popularity, in particular, SM. However, using this type of big data can also be associated with many problems. Recent study (Beer et al. 2018) identified the following barriers that inhibit economic development agencies to use big data in their operations:

1. limited skills in the manipulation and interpretation of big data, including familiarity with and capacity to use data sets and technology platforms/data sources,

2. tightly constrained staff time to work on data analysis and the development of measures,

3 . budget restrictions for performance measurement,

4. concerns over the reliability, security and ethical use of big data, and

5. government and agency silos restricting access to data.

Moreover McCreary et al. (2019) noticed many restrictions on the use of SM as a database. They are related to the representativeness of the data and the possibility of generalising the results as the themes presented here pertain to that narrow section of individuals represented by Instagram users. For example, there is concern about the 'social and spatial representativeness' of UGC data, as many Instagram users are between 18 and 29 years old (Dischinger et al. 2007). Additionally, as other researchers utilising UGC have identified, there are some individuals who will not be inclined to post, such as those who are participating in a hands-on experience such as fishing, and can or would not use their phone to capture an image at that moment (Wood et al. 2013). The fact that the data collected do not represent all of the relevant information should be the in minds of the researchers who should present a convincing argument of how the missing data may or may not affect their analysis (Metaxas, Mustafaraj 2014). Understanding the antecedents of the tourists' use of these technologies is considered to be crucial for organisation managers and destination policymakers (Parra-López et al. 2011). With the current state of knowledge, UGC should be integrated with 
other data during destination planning or marketing efforts; it can be used to identify the key attributes of a place that can be assessed through more generalisable research designs and methods. Information needs of economic development agencies and DMO represent and have to satisfy the needs of many stakeholders (e.g. elected members of council, taxpayers, (tourism) firms, governments at all levels, associations, trade unions), who have various (and sometimes conflicting) interests. Balancing the priorities and needs of these various stakeholders is not easy, though the provision of performance evidence is important for achieving the former (Sigala et al. 2019). SM is increasingly used as big data to fulfil these information needs. In addition to many advantages of this type of database presented inter alia by Metaxas, Mustafaraj (2014) and Sigala et al. (2019), it is not without risks and limitations (e.g. privacy, ethical and accuracy/reliability issues) (Raguseo 2018).

\section{Social media in tourism}

Kaplan and Haenlein (2010) define SM as $a$ group of Internet-based applications that build on the ideological and technological foundations of Web 2.0 and that allow the creation and exchange of user-generated content. Thus, like the authors of other definitions (Zeng et al. 2010, Fischer, Reuber 2011, Fotis et al. 2011, Kietzmann et al. 2011, Dabner 2012) they indicate the product of SM activity - UGC. SM as the source of big data has many advantages from the point of view of teams preparing tourism development plans. Big data is spatially and time based, as well as complex, i.e. generated from various users and sources. The characteristics of big data (Gandomi, Haider 2015, Lehrer et al. 2018) can significantly address the information needs for economic development measurement. Analytically, technology advances (sensors, SM, web-based tools) generate data in high volumes (large-scale data), at high velocity (high-speed real time data), in wide variety (data variability in the form of e.g. soft and hard data, text-based data and numerical data) and with a high level of veracity (multiple interpretations and a lot of 'noise', e.g. big data quality and reliability) (Sigala et al. 2019). Other advantages of content generated in SM include important information for the tourism economy, omitted in official statistics (e.g. about accommodation provided under Couchsurfing, Airbnb, or Uber services); in addition big data can support citizen/ stakeholder engagement in economic development performance measurement by crowdsourcing data collection (Sigala et al. 2019). Günther et al. (2017) identified two additional features of big data that can help organisations realise value from big data. These features (namely portability and interconnectivity) related to the organisational context of big data are used rather than their technological features. A review of the articles indicates that users are eager to share their experiences on the Internet, including travel experiences (Fotis et al. 2011). The entries generated by them constitute a set of data that, after prior arrangement, can be a valuable source of information on consumer preferences in the tourism market (Polańska, Wassilew 2015). In a rapidly changing society, it is necessary to constantly analyse the generated data streams because it is possible to catch signals indicating the emergence of a new trend from the emerging information noise (Brynjolfsson, McAfee 2012). The literature analysis indicated the thematic areas of SM functioning, which could be a valuable source of data useful at particular stages of tourism planning. They are:

1. the behaviour of tourists, making a decision on a tourist trip,

2. satisfaction and dissatisfaction of tourists,

3. image management,

4. reliability and usefulness of the opinion.

Research on the impact of SM on tourists' behaviour mainly involved looking for patterns of conduct, selection of places and products. Particular attention was paid to the hotel industry, links between feelings and user reviews were examined (Geetha et al. 2017), differences between independent and chain hotels (Banerjee, Chua 2016) and business travellers' ratings (Radojevic et. al. 2018), as well as differences in device from which they were added (Mariani et al. 2019) and in the utility of general and particular online hotel ratings (Park, Nicolau 2017). Research topics also referred to the decision-making process at the planning stage (Vermeulen, Seegers 2009, Grimm, Needham 2012, Amaro, Duarte 2015, Narangajavana et al. 2017, Liu et al. 2018), implementation (Wu, Pearce 2014) and 
travel coverage (Lee, $\mathrm{Hu}$ 2005, Wu et al. 2014, Hu et al. 2019). Issues related to the motives of using SM (Ayeh et al. 2013, Munar, Jacobsen 2014, Ukpabi, Karjaluoto 2018), the impact of reviews on the choice made (Vermeulen, Seegers 2009, Jacobsen, Munar 2012, Amaro, Duarte 2015), the problem of information overload (Fang et al. 2016), the importance of reviews in the decision-making process (Papathanassis, Knolle 2011) and their impact on formulating expectations (Lee, Gretzel 2012, Önder, Marchiori 2017) were discussed. A relatively new trend is research devoted to photography. They related to the phenomena associated with photographing and sharing images in SM (Lo et al. 2011), such as self-presentation (Dinhopl, Gretzel 2016, Lyu 2016, Nikjoo, Bakhshi 2019), or the phenomenon of photographing food (Wong et al. 2019). The subject of many studies on SM is satisfaction as well as dissatisfaction of users. The research focused on dissatisfaction related to hotel guests' dissatisfaction (Liu et al. 2017), experiences in wildlife tourism (Prakash et al. 2018), as well as the impact of responses to negative comments on consumer confidence (Levy et al. 2013, Sparks et al. 2016, Li et al. 2017). On the other hand, satisfaction surveys focused mainly on online review management (Nguyen, Coudounaris 2015) and linking the expectations created by SM with the real tourist offer (Narangajavana et al. 2017). The image of a tourist destination is more and more dependent on information generated by tourists, residents and entrepreneurs (Llodrà-Riera et al. 2015). SM is becoming an increasingly popular marketing tool for destination and image management. The research included the impact of reviews on image management (Phillips et al. 2015, Baka 2016, Lui et al. 2018) and the role of residents in creating it (Uchinaka et al. 2019). In terms of destination marketing, the users' involvement in tourist brands was examined (Cabiddu et al. 2014, Harrigan et al. 2017). An important often discussed in the literature issue in the context of SM is the credibility of the published content. Research in this matter concerns such areas as the consequences of false opinions (Filieri et al. 2015) or features of reliable opinions (Filieri 2016). The issue of the usefulness of opinions (Liu et al. 2015) and the motives for publishing them was also discussed (Munar, Jacobsen 2014, Liu et al. 2019a).

\section{Social media as a data bank}

The development of the Internet has resulted in the emergence of new research methods adapted to its specificity. One of them is netnography, which adapts ethnographic research techniques to study communities and cultures emerging on the Internet and uses publicly available content as part of a research sample (Kozinets 2010). This method is mainly based on field research, with a certain degree of participation and interaction with the online community (Woodside et al. 2007). Netnography provides information about consumers' patterns of online behaviour, revealing their hidden desires, experiences and expectations (Tavakoli, Wijesinghe 2019). Content published by SM users is varied in form (Giglio et al. 2019). Recognising them is important because it determines how they will be collected, stored and analysed. Research in the field of tourism mainly concerns opinions published by travellers in the form of star ratings (Lee, Gretzel 2012, Park, Nicolau 2015, Moro et al. 2017, Lui et al. 2018), reviews (Muchazondida, Markwell 2014, Wong, Qi 2017, Yan et al. 2018) as well as photographs (Lo et al. 2011, Kim, Stepchenkova 2015, Dinhopl, Gretzel 2016, Lyu 2016, Agustí 2018, Nikjoo, Bakhshi 2019, Wong et al. 2019). The analysis of the star rating is carried out using advanced mathematical models (Torres et al. 2014). They allow, among others, to explain how ratings affect sales and revenue (Ye et al. 2009), what is the relationship between the ratings and traffic volume on the website (Zhang et al. 2010) or the segmentation of the users (Kirilenko et al. 2019).

Reviews published by SM users are analysed using text mining methods. These methods are aimed at extracting keywords from the unstructured text data (e.g. user comments), as well as analysing the correlation between them. This allows for the identification of behavioural patterns and provides relevant information on the behaviour and interaction between people (Moro et al. 2017). The tests can be carried out manually or by a computer, while the research sample for manual analysis is much more limited (Levy et al. 2013, Mankad et al. 2016), and the result largely depends on the expert's knowledge (Zhou et al. 2014). Simple computer methods are limited to extracting the list of the most common words, without examining the correlation between them 
(Lee, Hu 2005, Li et al. 2013b). The result is that the conclusions can often be unclear and confusing (Büschken, Allenby 2016). More advanced methods, such as the Latent Dirichlet Allocation method, allow recognising the correlation between words (Guo et al. 2017). A relatively new trend in the analysis of SM is the study of the content of photographs made available on social networks. Due to the specificity of this format, the analysis is done manually and with a limited sample. The feature of data generated on social networking sites is a high degree of dispersion, which causes difficulties in their collection and analysis using standard statistical software (Muñiz, Schau 2011). Resources with such characteristics are referred to as big data (Snijders et al. 2012). Big data seems to be strongly related to the existing methods of data analysis; however, there are several features that constitute a new challenge. These include volume, velocity and variety (Cuesta et al. 2013).

Although the collection and storage costs have significantly decreased in recent years, the rapid increase in the amount of data is still a big problem. In 1992, daily 100 GB of data was generated, in 1997 this amount of data appeared in every hour and in 2002 already in every second. It is estimated that in 2018, every second the world will be enriched by 50,000 GB of data (Marr 2018). In times when an immediate response to emerging trends is important, such an impressive growth of data is a separate issue. The speed here refers both to the rate of increase of the abundance of the previously defined database with new records and to the addition of new sources appearing at any time. Quick response allows you to observe events almost when they occur. Big data is characterised by a large diversity, and it allows integrating data from separate sources, each of which is described by its own semantics. These can be, for example, data from GPS, social networks or transaction data. The challenge is to combine all data sets together so that they can be simultaneously analysed within one logical model. Data obtained from SM can be analysed in many ways, each of which requires the use of appropriate tools. The ratings that users give products on the rating portals can be collected in the form of a quantitative database. Acquiring these data and organising them allows obtaining information about the degree of satisfaction with individual services.
Many portals, apart from the general assessment of the facility, allow adding partial grades, which allow obtaining more detailed information about the object or the user adding opinions. The Booking.com portal evaluates the hotel based on ratings regarding cleanliness, location or value for money, which allows for a more in-depth analysis, e.g. identification of the best location due to the opinions of guests visiting hotels. The Tripadvisor portal, by contrast, classifies reviews by the type of traveller, as well as by the season in which the object was visited. This provides relevant information about the consumer's profile, e.g. whether the restaurant is more likely to be visited by families with children or perhaps by people travelling for business purposes. Descriptive reviews are a separate scope for analysis. A characteristic feature of the content of the review is the occurrence of repeating words that are identifiable using appropriate tools for text exploration. Identifying the words-attributes for a given location makes it possible to recognise the features that have the greatest impact on tourist traffic. Modern software not only identifies characteristic words but also links between them. This tool is applicable when analysing a positive or negative image, thus allowing to identify areas that attract tourists, as well as those that cause their dissatisfaction (Nowacki 2017). Photos published by users can also be a valuable source of information. The value here is, first, the possibility of comparing photographs posted by tourist companies and those presenting the actual state, as well as the analysis of the substantive content of the photos, which allows understanding what object or action makes the place very popular. In addition, posting a photo in the review significantly increases its credibility of the opinion.

SM are increasingly used as tools for managing the image of a tourist destination. The SM marketing model is a relatively new issue. It derives from the theory of tribal marketing, based on the phenomenon of building groups around a specific brand (Cova, Cova 2002). It is readily used by enterprises present in SM to create socalled brand communities whose members have the opportunity to exchange views and interact with the producer (Grębosz et al. 2016). The phenomenon of the accumulation of users around brands in SM is increasingly used in the sale and distribution of tourist products. The advertising 
campaign however should be multichannel, so that it is possible to reach as many groups of recipients as possible. The use of both social and traditional media results in higher efficiency than it does with the use of a single channel (Benckendorff et al. 2014). An example of such a campaign is marketing activities carried out on the Internet, which have met with so much interest among users that they have penetrated traditional media. Unusual and innovative advertising campaigns are readily commented on television news or radio broadcasts, thus gaining new recipients. The integrated marketing communication assumes that every communication channel has limitations, which campaign creators should be aware of (Duncan, Moriarty 1999).

\section{Social media as a tool for social communication}

$\mathrm{SM}$ is an important channel of communication with consumers in the area of improving the product offer. An interactive dialogue carried out with the help of this channel allows the clients to be involved in the process of designing and testing new solutions (Polańska, Wassilew 2015). Consultations of this type should, however, be carried out under appropriate conditions so that the information provided is narrowed to the areas of interest (Aaby, Discenza 2006). Griffin (2013) distinguishes two aspects necessary to reach the hidden needs of the consumer and make him a co-creator in the process of developing product innovations:

1. consumer statements should relate to functions and be based on experience related to products that were previously used by them,

2. they should describe their impressions and indicate problems which occurred during use, and the persons conducting the research should ask about the context, conditions and ways of using the product.

Undoubtedly, this definition is included in reviews posted by users. Some portals, in addition to adding reviews, enable dialogue between users. Von Hippel (2008) points to the role of key users in the process of creating product innovations. Among those who speak online in a given thematic area, there are also those with high motivation to co-create the product and have the necessary specialist knowledge. SM allows finding and contacting such users. Public consultations in the field of tourism development planning should involve a wide range of stakeholders, including residents, entrepreneurs and local organisations, and above all tourists. Especially valuable here are the opinions of people with extensive travel experience, which often manifests itself in high activity in tourist portals. These people can influence both the shaping of public opinion and the image of the tourist destination.

\section{Discussion}

A literature review in the field of tourism issues, taking into account the use of SM as databases or communication tools, has shown that so far there are no examples of comprehensive use of $\mathrm{SM}$ at all stages associated with the process of planning tourism development on a local scale. Previous studies, the results of which have been presented in the analysed articles, have taken into account the problems corresponding to selected stages of creating plans or their implementation (Table 2).

The reasons for this can be argued both in the specifics of planning and the implementation of plans - it is a process consisting of many stages, for which different teams are usually responsible for the resolution. Therefore, the use of SM as databases as well as communication tools is also done by teams in relation to the constrained stage of the planning process. A separate issue is that how reality check studies (IEDC 2014) show that despite the importance of performance measurement, more than 30\% economic development agencies do not measure their performance regularly. Research findings also provided the following reasons as to why organisations do not track their performance. Reasons refer not only to the difficulties of measurement studies but also to the deficiencies of data, methods and economic development agents to address measurement needs (Sigala et al. 2019).

On the other hand, scientific research of the entire planning process and implementation of tourism development plans and capacity utilisation in this priority of SM demand holistic and long-distance shots. Scientists, as demonstrated by the presented review of the literature, look 
Table 2. SM as a source of data and communication tools in tourism development planning.

\begin{tabular}{|c|c|c|c|}
\hline Planning stage & SM function & Research topics & Literature \\
\hline $\begin{array}{l}\text { Preparing research, } \\
\text { setting strategy goals }\end{array}$ & $\mathrm{DB}, \mathrm{SC}$ & $\begin{array}{l}\text { Recognising the needs for creat- } \\
\text { ing strategies }\end{array}$ & $\begin{array}{l}\text { Cabiddu et al. 2014, Önder, Marchiori } \\
\text { 2017, Wang et al. 2017, Ziegler et al. } \\
\text { 2018, Hu et al. 2019, Sinclair et al. } 2019\end{array}$ \\
\hline $\begin{array}{l}\text { Review of secondary } \\
\text { data }\end{array}$ & DB & $\begin{array}{l}\text { Identification of demand charac- } \\
\text { teristics - tourists' opinions, sat- } \\
\text { isfaction with the current tourist } \\
\text { offer and tourist migration routes }\end{array}$ & $\begin{array}{l}\text { Vermeulen, Seegers 2009, Li et al. } \\
\text { 2013a,b, Cong et al. 2014, Liu et al. 2017, } \\
\text { Radojevic et al. 2018, Giglio et al. 2019, } \\
\text { Hu et al. 2019, Nikjoo, Bakhshi 2019, } \\
\text { Yan et al. } 2019\end{array}$ \\
\hline $\begin{array}{l}\text { Collection of primary } \\
\text { data }\end{array}$ & SC & $\begin{array}{l}\text { Identification of the main prob- } \\
\text { lems of tourism development }\end{array}$ & $\begin{array}{l}\text { Boley et al. 2013, Cabiddu et al. 2014, } \\
\text { Cró, Martins 2017, Kirilenko et al. } 2019\end{array}$ \\
\hline $\begin{array}{l}\text { Analysis of secondary } \\
\text { and primary data }\end{array}$ & - & Data analysis methods & $\begin{array}{l}\text { Rong et al. 2012, Li et al. 2013a,b, } \\
\text { Stepchenkova, Zhan 2013, Chua et al. } \\
\text { 2016, Wong, Qi 2017, Marine-Roig, Fer- } \\
\text { rer-Rosell 2018, Hu et al. } 2019\end{array}$ \\
\hline $\begin{array}{l}\text { Policy initiation, formu- } \\
\text { lation of an action plan }\end{array}$ & SC & $\begin{array}{l}\text { Informing about the assumptions } \\
\text { of the formulated action plan }\end{array}$ & $\begin{array}{l}\text { Månsson 2011, Shao et al. 2016, Harrig- } \\
\text { an et al. 2017, Li et al. } 2017\end{array}$ \\
\hline Recommendations & SC & $\begin{array}{l}\text { Consultations on proposed devel- } \\
\text { opment scenarios }\end{array}$ & $\begin{array}{l}\text { Cabiddu et al. 2014, Harrigan et al. 2017, } \\
\text { Pantano et al. 2017, Mucha, Holder } 2019\end{array}$ \\
\hline Implementation & SC & Marketing activities & $\begin{array}{l}\text { Dijkmans et al. 2015, Llodrà-Riera et al. } \\
\text { 2015, Lo, McKercher 2015, Mariani et al. } \\
\text { 2016, Shao et al. } 2016\end{array}$ \\
\hline $\begin{array}{l}\text { Monitoring, evalua- } \\
\text { tion and verification of } \\
\text { activities }\end{array}$ & $\mathrm{DB}, \mathrm{SC}$ & $\begin{array}{l}\text { Assessment of the effects of the } \\
\text { implementation of the adopted } \\
\text { objectives for the development of } \\
\text { promoted tourism segments }\end{array}$ & $\begin{array}{l}\text { Radojevic et al. 2015, Wang et al. 2017, } \\
\text { Wong, Qi 2017, Boley et al. 2018, Ma- } \\
\text { rine-Roig, Ferrer-Rosell 2018, Ziegler et } \\
\text { al. 2018, Liu et al. 2019b }\end{array}$ \\
\hline
\end{tabular}

DB, data bank; SC, social communication.

rather at specific problems related to the selected phase of the planning process. The specificity of SM is a separate problem, in which data is generated individually, in relation to individual, and usually at local scale. It causes the need to search for effective methods of data collection and synthesis. As Sigala et al. (2019) aptly noted organisations nowadays have access to more data than they actually know how to analyse and what to do with it. Considering the huge potential of SM as databases and communication tools useful in the tourism development planning process, at this stage of knowledge development, project teams dealing with the collection, analysis and synthesis of data covering all stages of the beaching process should be established. It is a challenge for both teams of scientists (shaping methodology and theory) and practitioners (testing developed theoretical and methodological frameworks in a specific practical context). The results of big data project teams should contribute to the development of research methodology as well as guaranteeing current useful knowledge for teams making decisions about the shape of created and implemented plans.

\section{Conclusions}

The literature review showed that the main research problems that exist in regards to $\mathrm{SM}$ as a tourism planning tool were tourist behaviour and decision-making process, satisfaction and dissatisfaction, image management as well as credibility and usefulness of opinions. The research is fragmentary, it does not refer to the tourism development planning cycle, but rather focuses on narrower issues related to a specific planning stage. SM create both many opportunities and limitations as a potential source of a data bank and publicly available tools for social communication. Both of these functions can be used at various stages of tourism planning on a local scale. The main possibilities include providing information on the preferences of people visiting a given region, in the form of a data bank based on a large statistical sample (analyses of data from SM are conducted anonymously, so there is no problem with the ethics of social research). They also allow social communication with a wide range of stakeholders and the implementation of marketing activities of a tourist destination, reaching 
the right target group. The main limitation is dealing with dynamic, complex data bank that can be hard in rapidly changing SM platforms. Also the target group could be difficult to identify due to the fact of anonymous nature of the Internet use. Difficulties may also be generated by the policy of companies running social networking sites, associated with, for example, not disclosing the methods of creating rankings, which in turn causes difficulties in data interpretation.

The presented concept of tourism planning is based on well-known assumptions regarding planning and enriches them with new sources of information and communication channels such as SM. It allows to achieve a greater degree of social participation, and thus to achieve solutions better adapted to the expectations of different groups of stakeholders and adaptation to dynamically changing conditions. The versatility and diversity of forms in which SM occur, allows their use in many aspects of tourism development, from diagnosis to marketing of implemented changes.

However, many issues require detailed elaboration, above all in the methodological aspect. Previously published articles provide only rudimentary information on communication with stakeholder groups and data collection from tourist websites. These issues require further elaboration, in particular, in the process of creating and analysing a data bank, so that it is not time- and capital-intensive. An important issue is also determining the characteristics of SM users. One should not put forward a simple conclusion here that the popularity of the Internet and SM make them reflect the structure of society. Specifying the characteristics of UGC will allow to determine which segment of clients they represent and, therefore, whose expectations can be satisfied.

Planning for tourism development is a difficult task and requires constant learning, modifying existing methods and developing completely new ones that allow the use of information from further sources. The potential of SM has already been noticed in the works related to the tourism development planning process, but it is still a path full of new phenomena requiring a widespread diagnosis. Hence, at this stage of knowledge development, an important direction of research should be a holistic, long-term approach, covering the entirety of a given planning cycle and plan implementation. It is a challenge both for teams of scientists (shaping methodology and theory) and for the practitioners (testing developed theoretical and methodological frameworks in a specific practical context).

\section{Acknowledgements}

This research did not receive any specific grant from funding agencies in the public, commercial or not-for-profit sectors. We thank the reviewers for comments that improved the manuscript.

\section{Author contributions}

Alina Zajadacz 50\%, Aleksandra Minkwitz 50\%.

\section{References}

Aaby N., Discenza R., 2006. Strategic marketing and new product development. Journal of Business and Industrial Marketing 8(2): 61-62. DOI 10.1108/08858629310041357.

Agustí D.P, 2018. Characterizing the location of tourist images in cities. Differences in user-generated images (Instagram), official tourist brochures and travel guides. Annals of Tourism Research 73: 103-115. DOI 10.1016/j. annals.2018.09.001.

Allen S.D., Wickwar D.A., Clark F.P., Potts R., Snyder S.A., 2009. Values, beliefs, and attitudes technical guide for Forest Service land and resource management, planning, and decisionmaking. USDA Forest Service - General Technical Report PNW-GTR.

Amaro S., Duarte P., 2015. An integrative model of consumers' intentions to purchase travel online. Tourism Management 46: 64-79. DOI 10.1016/j.tourman.2014.06.00.

Ayeh J.K., Au N., Law R., 2013. Predicting the intention to use consumer-generated media for travel planning. Tourism Management 35: 132-143. DOI 10.1016/j.tourman.2012.06.010.

Baka V., 2016. The becoming of user-generated reviews: Looking at the past to understand the future of managing reputation in the travel sector. Tourism Management 53: 148-162. DOI 10.1016/j.tourman.2015.09.004.

Banerjee S., Chua A.Y.K., 2016. In search of patterns among travellers' hotel ratings in TripAdvisor. Tourism Management 53: 125-131. DOI 10.1016/j.tourman.2015.09.020.

Beer A., Hodgson L., Connor A.O., Sigala M., 2018. Development and Evaluation of Economic Development Measures. University of South Australia, Adelaide.

Benckendorff P., Sheldon P.J., Fesenmaier D.R., 2014. Tourism information technology. Online: books.google.pl/ books?id=Hye2BAAAQBAJ\&hl=pl\&source=gbs_book other_versions (accessed 21 August 2020).

Boley B., Magnini V.P., Tuten T.L., 2013. Social media picture posting and souvenir purchasing behavior: Some initial findings. Tourism Management 37: 27-30. DOI 10.1016/j. tourman.

Boley B.B., Jordan E.J., Kline C., Knollenberg W., 2018. Social return and intent to travel. Tourism Management 64: 119-128. DOI 10.1016/j.tourman. 
Brynjolfsson E., McAfee A., 2012. Big data: The management revolution. Harvard Business Review, 2012(10): 1-9. Online: hbr.org/2012/10/big-data-the-management-revolution (accessed 21 August 2020).

Büschken J., Allenby G.M., 2016. Sentence-based text analysis for customer reviews. Marketing Science 35(6): 953 975. DOI $10.1287 / \mathrm{mksc}$.

Cabiddu F., de Carlo M., Piccoli G., 2014. Social media affordances: Enabling customer engagement. Annals of Tourism Research 48: 175-192. DOI 10.1016/j.annals.

Chua A., Servillo L., Marcheggiani E., Moere A. Vande, 2016. Mapping Cilento: Using geotagged social media data to characterize tourist flows in southern Italy. Tourism Management 57: 295-310. DOI 10.1016/j.tourman.

Cong L., Wu B., Morrison A.M., Shu H., Wang M., 2014. Analysis of wildlife tourism experiences with endangered species: An exploratory study of encounters with giant pandas in Chengdu, China. Tourism Management 40: 300-310. DOI 10.1016/j.tourman.

Cova B., Cova V., 2002. Tribal marketing: The tribalisation of society and its impact on the conduct of marketing. European Journal of Marketing 36(5/6): 595-620. DOI 10.1108/03090560210423023.

Cró S., Martins A.M., 2017. The importance of security for hostel price premiums: European empirical evidence. Tourism Management 60: 159-165. DOI 10.1016/j.tourman.2016.11.021.

Cuesta C.E., Martínez-Prieto M.A., Fernández J.D., 2013. Towards an architecture for managing big semantic data in real-time. Springer, Berlin, Heidelberg. DOI 10.1007/9783-642-39031-9_5.

Dabner N., 2012. "Breaking Ground" in the use of social media: A case study of a university earthquake response to inform educational design with Facebook. Internet and Higher Education 15(1): 69-78. DOI 10.1016/j.iheduc.2011.06.001.

Dijkmans C., Kerkhof P., Beukeboom C.J., 2015. A stage to engage: Social media use and corporate reputation. Tourism Management 47: 58-67. DOI 10.1016/j.tourman.2014.09.005

Dinhopl A., Gretzel U., 2016. Selfie-taking as touristic looking. Annals of Tourism Research 57: 126-139. DOI 10.1016/j. annals.2015.12.015.

Dinis F.M.G., da Costa C.M.M., da Pacheco O.M.R., 2019. Composite indicators for measuring the online search interest by a tourist destination. In: M. Sigala, R. Rahimi, M. Thelwall (eds), Big data and innovation in tourism, travel, and hospitality: Managerial approaches, techniques, and applications. Springer, Singapore: 1-20.

Dischinger M., Hope D., Gries C., Zhu W., Fagan W.F., Redman C.L., Vergurg P.H., 2007. Continental scale quatification of landscape values using social media data. PNAS 113(46): 12974-12979. DOI 10.1073/pnas.

Duncan T., Moriarty S., 1999. Commentary on Relationship-based marketing communication. Australasian Marketing Journal 7(1): 118-120.

EPA [Environmental Protection Agency], 2020. Community culture and the environment: A guide to understanding a sense of place. Online: conservationtools-production.s3.amazonaws.com/library_item_files/450/500/ community_culture.pdf?AWSAccessKeyId=AKIAIQFJLILYGVDR4AMQ\&Expires=1598462887\&Signature $=q H U U C I A x u G 17 L 111 G l i 1 J p b n Z T k \% 3 D \quad$ (accessed 21 August 2020).

Fang B., Ye Q., Kucukusta D., Law R., 2016. Analysis of the perceived value of online tourism reviews: Influence of readability and reviewer characteristics. Tourism Management 52: 498-506. DOI 10.1016/j.tourman.

Filieri R., 2016. What makes an online consumer review trustworthy? Annals of Tourism Research 58: 46-64. DOI 10.1016/j.annals.2015.12.019.

Filieri R., Alguezaui S., McLeay F., 2015. Why do travelers trust TripAdvisor? Antecedents of trust towards consumer-generated media and its influence on recommendation adoption and word of mouth. Tourism Management 51: 174-185. DOI 10.1016/j.tourman.2015.05.007.

Fischer E., Reuber A. R., 2011. Social interaction via new social media: (How) can interactions on Twitter affect effectual thinking and behavior? Journal of Business Venturing 26(1): 1-18. DOI 10.1016/j.jbusvent.

Fletcher J., 2005. The tourism development planning process. In: Cooper C.H., Fletcher J., Fyall A., Gilbert D., Wanhill S. (eds), Tourism Principles and Practice. Pearson Educational Limited: 296-331, Harlow.

Fotis J., Buhalis D., Rossides N., 2011. Social media impact on holiday travel planning: The case of the Russian and the FSU markets. International Journal of Online Marketing 1(4): 1-19.

Gandomi A., Haider M., 2015. Beyond the hype: Big data concepts, methods, and analytics. International Journal of Information Management 35(2): 137-144. DOI 10.1016/j. ijinfomgt.

Geetha M., Singha P., Sinha S., 2017. Relationship between customer sentiment and online customer ratings for hotels - An empirical analysis. Tourism Management 61: 43-54. DOI 10.1016/j.tourman.

Giglio S., Bertacchini F., Bilotta E., Pantano P., 2019. Using social media to identify tourism attractiveness in six Italian cities. Tourism Management 72: 306-312. DOI 10.1016/j. tourman.

Grębosz M., Siuda D., Szymański G., 2016. Social media marketing. Wydawnictwo Politechniki Łódzkiej, Łódź.

Griffin A., 2013. Obtaining customer needs for product development. In: Kahn K. (eds), The PDMA Handbook of New Product Development. John Wiley \& Sons, Inc., Hoboken, New Jersey: 213-230. DOI 10.1002/9781118466421.ch13.

Grimm K.E., Needham M.D., 2012. Internet promotional material and conservation volunteer tourist motivations: A case study of selecting organizations and projects. Tourism Management Perspectives 1(1): 17-27. DOI 10.1016/j. tmp.2011.12.007.

Günther W.A., Mehrizi M.H.R., Huysman M., Feldberg F., 2017. Debating big data: A literature review on realizing value from big data. Journal of Strategic Information Systems 26(3): 191-209. DOI 10.1016/j.jsis.2017.07.003.

Guo Y., Barnes S.J., Jia Q., 2017. Mining meaning from online ratings and reviews: Tourist satisfaction analysis using latent dirichlet allocation. Tourism Management 59: 467483. DOI 10.1016/j.tourman.2016.09.009.

Harrigan P., Evers U., Miles M., Daly T., 2017. Customer engagement with tourism social media brands. Tourism Management 59: 597-609. DOI 10.1016/j.tourman.2016.09.015

Hu N., Zhang T., Gao B., Bose I., 2019. What do hotel customers complain about? Text analysis using structural topic model. Tourism Management 72: 417-426. DOI 10.1016/j. tourman.2019.01.002.

IEDC [International Economic Development Council], 2014. Making it count: metrics for high performing EDOs. Washington.

Jacobsen J.K.S., Munar A.M., 2012. Tourist information search and destination choice in a digital age. Tour- 
ism Management Perspectives 1(1): 39-47. DOI 10.1016/j. tmp.2011.12.005.

Jennings G., 2010. Tourism research. Wily Australia Tourism Series, Milton.

Kaplan A.M., Haenlein M., 2010. Users of the world, unite! The challenges and opportunities of Social Media. Business Horizons 53(1): 59-68. DOI 10.1016/j.bushor.2009.09.003.

Kietzmann J.H., Hermkens K., Mccarthy I.P., Silvestre B.S., 2011. Social media ? Get serious! Understanding the functional building blocks of social media. Business Horizons 54(3): 241-251. DOI 10.1016/j.bushor.2011.01.005.

Kim G.H., Trimi S., Chung J.H., 2014. Big-data applications in the government sector. Communications of the ACM 57(3): 78-85. DOI 10.1145/2500873.

Kim H., Stepchenkova S., 2015. Effect of tourist photographs on attitudes towards destination: Manifest and latent content. Tourism Management 49: 29-41. DOI 10.1016/j.tourman.2015.02.004.

Kirilenko A.P., Stepchenkova S.O., Hernandez J.M., 2019. Comparative clustering of destination attractions for different origin markets with network and spatial analyses of online reviews. Tourism Management 72: 400-410. DOI 10.1016/j.tourman.2019.01.001

Kozinets R.V., 2010. Netnography: Doing ethnographic research online. International Journal of Advertising. DOI 10.2501/S026504871020118X.

Lavertu S., 2016. We all need help: "Big Data" and the mismeasure of public administration. Public Administration Review 76(6): 864-872. DOI 10.1111/puar.12436.

Lee C.C., Hu C.,2005. Analyzing hotel customers' e-complaints from an Internet complaint forum. Journal of Travel and Tourism Marketing 17(2-3): 167-181. DOI 10.1300/ j073v17n02_13.

Lee W., Gretzel U., 2012. Designing persuasive destination websites: A mental imagery processing perspective. Tourism Management 33(5): 1270-1280. DOI 10.1016/j.tourman.2011.10.012.

Lehrer C., Wieneke A., vom Brocke J., Jung R., Seidel S., 2018. How big data analytics enables service innovation: Materiality, affordance, and the individualization of service. Journal of Management Information Systems 35(2): 424-460. DOI 10.1080/07421222.2018.1451953.

Levy S.E., Duan W., Boo S., 2013. An analysis of one-star online reviews and responses in the Washington, D.C., lodging market. Cornell Hospitality Quarterly 54(1): 49-63. DOI 10.1177/1938965512464513.

Li C., Cui G., Peng L., 2017. The signaling effect of management response in engaging customers: A study of the hotel industry. Tourism Management 62: 42-53. DOI 10.1016/j.tourman.2017.03.009.

Li G., Law R., Vu H.Q., Rong J., 2013a. Discovering the hotel selection preferences of Hong Kong inbound travelers using the Choquet Integral. Tourism Management 36, 321-330. DOI 10.1016/j.tourman.2012.10.017.

Li H., Ye Q., Law R., 2013b. Determinants of customer satisfaction in the hotel industry: An application of online review analysis. Asia Pacific Journal of Tourism Research 18(7): 784-802. DOI 10.1080/10941665.2012.708351.

Liu X., Schuckert M., Law R., 2018. Utilitarianism and knowledge growth during status seeking: Evidence from text mining of online reviews. Tourism Management 66: 38-46. DOI 10.1016/j.tourman.2017.11.005.

Liu X., Zhang Z., Law R., Zhang Z., 2019a. Posting reviews on OTAs: Motives, rewards and effort. Tourism Management 70: 230-237. DOI 10.1016/j.tourman.2018.08.013.
Liu Y., Huang K., Bao J., Chen K., 2019b. Listen to the voices from home: An analysis of Chinese tourists' sentiments regarding Australian destinations. Tourism Management 71: 337-347. DOI 10.1016/j.tourman.2018.10.004.

Liu Y., Teichert T., Rossi M., Li H., Hu, F., 2017. Big data for big insights: Investigating language-specific drivers of hotel satisfaction with 412,784 user-generated reviews. Tourism Management 59: 554-563. DOI 10.1016/j.tourman.2016.08.012

Liu Z., Park S., 2015. What makes a useful online review? Implication for travel product websites. Tourism Management 47: 140-151. DOI 10.1016/j.tourman.2014.09.020.

Liu Z., Siguaw J.A., Enz C.A., 2008. Using tourist travel habits and preferences to assess strategic destination positioning: The case of Costa Rica. Cornell Hospitality Quarterly 49(3): 258-281. DOI 10.1177/1938965508322007.

Llodrà-Riera I., Martínez-Ruiz M.P., Jiménez-Zarco A.I., Izquierdo-Yusta A., 2015. A multidimensional analysis of the information sources construct and its relevance for destination image formation. Tourism Management 48: 319-328. DOI 10.1016/j.tourman.2014.11.012.

Lo I.S., McKercher B., 2015. Ideal image in process: Online tourist photography and impression management. Annals of Tourism Research 52: 104-116. DOI 10.1016/j.annals.2015.02.019.

Lo I.S., McKercher B., Lo, A. Cheung, C., Law, R., 2011. Tourism and online photography. Tourism Management 32(4): 725-731. DOI 10.1016/j.tourman.2010.06.001.

Lui T.W., Bartosiak M., Piccoli G., Sadhya V., 2018. Online review response strategy and its effects on competitive performance. Tourism Management 67: 180-190. DOI 10.1016/j.tourman.2018.01.014.

Lyu S.O., 2016. Travel selfies on social media as objectified self-presentation. Tourism Management 54: 185-195. DOI 10.1016/j.tourman.2015.11.001.

Mankad S., "Spring" Han H., Goh, J., Gavirneni S., 2016. Understanding online hotel reviews through automated text analysis. Service Science 8(2): 124-138. DOI 10.1287/ serv.2016.0126.

Månsson M., 2011. Mediatized tourism. Annals of Tourism Research 38(4): 1634-1652. DOI 10.1016/j.annals.2011.02.008.

Mariani M.M., Borghi M., Gretzel U., 2019. Online reviews: Differences by submission device. Tourism Management 70: 295-298. DOI 10.1016/j.tourman.2018.08.022.

Mariani M.M., Di Felice M., Mura M., 2016. Facebook as a destination marketing tool: Evidence from Italian regional destination management organizations. Tourism Management 54: 321-343. DOI 10.1016/j.tourman.2015.12.008.

Marine-Roig E., Ferrer-Rosell B., 2018. Measuring the gap between projected and perceived destination images of Catalonia using compositional analysis. Tourism Management 68: 236-249. DOI 10.1016/j.tourman.2018.03.020.

Marr B., 2018. How Much Data Do We Create Every Day? The Mind-Blowing Stats Everyone Should Read. Online: www.forbes.com/sites/bernardmarr/2018/05/21/ how-much-data-do-we-create-every-day-the-mindblowing-stats-everyone-should-read/\#3682c5e060ba (accessed 21 August 2020).

McCreary A., Seekamp E., Davenport M., Smith J.W., 2019. Exploring qualitative applications of social media data for place-based assessments in destination planning. Current Issues in Tourism 23(1): 82-98. DOI 10.1080/13683500.2019.1571023.

Metaxas P., Mustafaraj E., 2014. Sifting the sand on the river bank: Social media as a source for research data. It - Infor- 
mation Technology 56(5): 230-239. DOI 10.1515/itit-20141047.

Moro S., Rita P., Coelho J., 2017. Stripping customers' feedback on hotels through data mining: The case of Las Vegas Strip. Tourism Management Perspectives 23: 41-52. DOI 10.1016/j.tmp.2017.04.003.

Mucha M., Holder A., 2019. The future of animals in tourism recreation: Social media as spaces of collective moral reflexivity. Tourism Management Perspectives 29: 1-8. DOI 10.1016/j.tmp.2018.10.002.

Muchazondida M., Markwell K., 2014. The application of netnography in tourism studies. Annals of Tourism Research 48: 289-291. DOI 10.1016/j.annals.2014.07.005.

Munar A.M., Jacobsen J.K.S., 2014. Motivations for sharing tourism experiences through social media. Tourism Management 43: 46-54. DOI 10.1016/j.tourman.2014.01.012.

Muñiz A.M., Schau H.J., 2011. How to inspire value-laden collaborative consumer-generated content. Business Horizons 54(3): 209-217. DOI 10.1016/j.bushor.2011.01.002.

Narangajavana Y., Callarisa Fiol L.J., Moliner Tena M.Á., Rodríguez Artola R.M., Sánchez García J., 2017. The influence of social media in creating expectations. An empirical study for a tourist destination. Annals of Tourism Research 65: 60-70. DOI 10.1016/j.annals.2017.05.002.

Nguyen K.A., Coudounaris D.N., 2015. The mechanism of online review management: A qualitative study. Tourism Management Perspectives 16: 163-175. DOI 10.1016/j. tmp.2015.08.002.

Nikjoo A., Bakhshi H., 2019. The presence of tourists and residents in shared travel photos. Tourism Management 70: 89-98. DOI 10.1016/j.tourman.2018.08.005.

Nowacki M., 2017. Atrakcje turystyczne światowych metropolii w opinii użytkowników TripAdvisora. Studia Periegetica 3: 23-41.

Önder I., Marchiori E., 2017. A comparison of pre-visit beliefs and projected visual images of destinations. Tourism Management Perspectives 21: 42-53. DOI 10.1016/j. tmp.2016.11.003.

Pantano E., Priporas C.V., Stylos N., 2017. 'You will like it!' using open data to predict tourists' response to a tourist attraction. Tourism Management 60: 430-438. DOI 10.1016/j.tourman.2016.12.020.

Papathanassis A., Knolle F., 2011. Exploring the adoption and processing of online holiday reviews: A grounded theory approach. Tourism Management 32(2): 215-224. DOI 10.1016/j.tourman.2009.12.005.

Park S., Nicolau J.L., 2015. Asymmetric effects of online consumer reviews. Annals of Tourism Research 50: 67-83. DOI 10.1016/j.annals.2014.10.007.

Park S., Nicolau J.L., 2017. Effects of general and particular online hotel ratings. Annals of Tourism Research 62: 114116. DOI 10.1016/j.annals.2016.10.010.

Parra-López E., Bulchand-Gidumal J., Gutiérrez-Taño D., Díaz-Armas R., 2011. Intentions to use social media in organizing and taking vacation trips. Computers in Human Behavior 27: 640-654. DOI 10.1016/j.chb.2010.05.022.

Phillips P., Moutinho L., 2014. Critical review of strategic planning research in hospitality and tourism. Annals of Tourism Research 48: 96-120. DOI 10.1016/j.annals.2014.05.013.

Phillips P., Zigan K., Santos Silva M.M., Schegg, R,. 2015. The interactive effects of online reviews on the determinants of Swiss hotel performance: A neural network analysis. Tourism Management 50: 130-141. DOI 10.1016/j.tourman.2015.01.028.
Polańska K., Wassilew A., 2015. Analizy big data w serwisach społecznościowych (Big data analyzes on social networks). Nierówności Społeczne a Wzrost Gospodarczy, 44(2): 117-128. DOI 10.15584/nsawg.2015.4.2.11.

Prakash S.L., Perera P., Newsome D., Kusuminda T., Walker O., 2018. Reasons for visitor dissatisfaction with wildlife tourism experiences at highly visited national parks in Sri Lanka. Journal of Outdoor Recreation and Tourism 25(July): 102-112. DOI 10.1016/j.jort.2018.07.004.

Radojevic T., Stanisic N., Stanic N., 2015. Ensuring positive feedback: Factors that influence customer satisfaction in the contemporary hospitality industry. Tourism Management 51: 13-21. DOI 10.1016/j.tourman.2015.04.002.

Radojevic T., Stanisic N., Stanic N., Davidso, R., 2018. The effects of traveling for business on customer satisfaction with hotel services. Tourism Management 67: 326-341. DOI 10.1016/j.tourman.2018.02.007.

Raguseo E., 2018. Big data technologies: An empirical investigation on their adoption, benefits and risks for companies. International Journal of Information Management 38(1): 187-195. DOI 10.1016/j.ijinfomgt.2017.07.008.

Richards D.R., Friess D.A., 2015. A rapid indicator of cultural ecosystem service usage at a fine spatial scale: Content analysis of social media photographs. Ecological Indicators 53: 187-195. DOI 10.1016/j.ecolind.2015.01.034.

Rong J., Vu H. Q., Law R., Li, G., 2012. A behavioral analysis of web sharers and browsers in Hong Kong using targeted association rule mining. Tourism Management 33(4): 731-740. DOI 10.1016/j.tourman.2011.08.006.

Shao J., Li X., Morrison A.M., Wu, B., 2016. Social media micro-film marketing by Chinese destinations: The case of Shaoxing. Tourism Management 54: 439-451. DOI 10.1016/j.tourman.2015.12.013.

Sigala M., Beer A., Hodgson L., O'Connor A., 2019. Big data for measuring the impact of tourism economic development programmes: A process and quality criteria framework for using big data. In: Sigala M., Rahimi R., Thelwall M. (eds), Big data and innovation in tourism, travel, and hospitality. managerial approaches, techniques, and applications. Springer, Singapore: 57-74.

Sinclair M., Ghermandi A., Moses S.A., Joseph S., 2019. Recreation and environmental quality of tropical wetlands: A social media based spatial analysis. Tourism Management 71(2751): 179-186. DOI 10.1016/j.tourman.2018.10.018.

Snijders C., Matzat U., Reips U.D., 2012. Big data: Big gaps of knowledge in the field of Internet science. International Journal of Internet Science 2012(1): 1-5.

Sonter L.J., Watson K.B., Wood S.A., Ricketts T.H., 2016. Spatial and temporal dynamics and value of nature-based recreation, estimated via social media. PLOS ONE 11(9). DOI 10.1371/journal.pone.0162372.

Sparks B.A., So K.K.F., Bradley G.L., 2016. Responding to negative online reviews: The effects of hotel responses on customer inferences of trust and concern. Tourism Management 53: 74-85. DOI 10.1016/j.tourman.2015.09.011.

Stepchenkova S., Zhan F., 2013. Visual destination images of Peru: Comparative content analysis of DMO and user-generated photography. Tourism Management 36: 590-601. DOI 10.1016/j.tourman.2012.08.006.

Tavakoli R., Wijesinghe S.N.R., 2019. The evolution of the web and netnography in tourism: A systematic review. Tourism Management Perspectives 29: 48-55. DOI 10.1016/j.tmp.2018.10.008.

Torres E.N., Adler H., Behnke C., 2014. Stars, diamonds, and other shiny things: The use of expert and consum- 
er feedback in the hotel industry. Journal of Hospitality and Tourism Management 21: 34-43. DOI 10.1016/j. jhtm.2014.04.001.

Tribe J., 2016. Strategy for tourism. Strategy for tourism. Goodfellow Publisher Limited. Online: www.cabdirect.org/ cabdirect/abstract/20163329441 (accessed 21 August 2020).

Uchinaka S., Yoganathan V., Osburg V.S., 2019. Classifying residents' roles as online place-ambassadors. Tourism Management 71: 137-150. DOI 10.1016/j.tourman.2018.10.008

Ukpabi D.C., Karjaluoto H., 2018. What drives travelers' adoption of user-generated content? A literature review. Tourism Management Perspectives 28(March): 251-273. DOI 10.1016/j.tmp.2018.03.006.

UNWTO [United Nations World Tourism Organization], 2017. Tourism highlights 2017 edition. DOI 10.18111/9789284419029.

Van Berkel D.B., Tabrizian P., Dorning M.A., Smart L., Newcomb D., Mehaffey M., Meentemeyer R.K., 2018. Quantifying the visual-sensory landscape qualities that contribute to cultural ecosystem services using social media and LiDAR. Ecosystem Services 31: 326-335. DOI 10.1016/j. ecoser.2018.03.022

Vermeulen I.E., Seegers D., 2009. Tried and tested: The impact of online hotel reviews on consumer consideration. Tourism Management 30(1): 123-127. DOI 10.1016/j.tourman.2008.04.008.

Von Hippel E., 2008. Lead users: A source of novel product concepts. Management Science 32(7): 791-793. DOI 10.1287/mnsc.32.7.791.

Wang S., Kirillova K., Lehto X., 2017. Reconciling unsatisfying tourism experiences: Message type effectiveness and the role of counterfactual thinking. Tourism Management 60: 233-243. DOI 10.1016/j.tourman.2016.12.008.

Wong C.U.I., Qi S., 2017. Tracking the evolution of a destination's image by text-mining online reviews - the case of Macau. Tourism Management Perspectives 23: 19-29. DOI 10.1016/j.tmp.2017.03.009.

Wong I.K.A., Liu D., Li N., Wu S., Lu L., Law R., 2019. Foodstagramming in the travel encounter. Tourism Management 71: 99-115. DOI 10.1016/j.tourman.2018.08.020.

Wood S.A., Guerry A.D., Silver J.M., Lacayo M,. 2013. Using social media to quantify nature-based tourism and recreation. Scientific Reports 3(2976). DOI 10.1038/srep02976.

Woodside A.G., Cruickshank B.F., Dehuang, N., 2007. Stories visitors tell about Italian cities as destination icons. Tourism Management 28(1): 162-174. DOI 10.1016/j.tourman.2005.10.026.
Wu M.Y., Pearce P.L., 2014. Chinese recreational vehicle users in Australia: A netnographic study of tourist motivation. Tourism Management 43, 22-35. DOI 10.1016/j. tourman.2014.01.010.

Wu M.Y., Wall G., Pearce P.L., 2014. Shopping experiences: International tourists in Beijing's Silk Market. Tourism Management 41: 96-106. DOI 10.1016/j.tourman.2013.09.010.

Yan L., Xu J. (Bill), Sun Z., Xu Y., 2019. Street art as alternative attractions: A case of the East Side Gallery. Tourism Management Perspectives 29: 76-85. DOI 10.1016/j. tmp.2018.11.001.

Yan Q., Zhou S., Wu S., 2018. The influences of tourists' emotions on the selection of electronic word of mouth platforms. Tourism Management 66, 348-363. DOI 10.1016/j. tourman.2017.12.015.

Ye Q., Law R., Gu B., 2009. The impact of online user reviews on hotel room sales. International Journal of Hospitality Management 28(1): 180-182. DOI 10.1016/j. ijhm.2008.06.011.

Yoshimura N., Hiura T., 2017. Demand and supply of cultural ecosystem services: Use of geotagged photos to map the aesthetic value of landscapes in Hokkaido. Ecosystem Services 24: 68-78. DOI 10.1016/j.ecoser.2017.02.009.

Yung L., Freimund W.A., Belsky J.M., 2003. The politics of place: Understanding meaning, common ground, and political difference on the Rocky Mountain Front. Forest Science 49(6): 855-866. DOI 10.1093/forestscience/49.6.855.

Zajadacz A., 2017. Social media in the planning process of tourism development on a regional scale. Ekonomiczne Problemy Turystyki 1(37): 127-146. DOI 10.18276/ ept.2017.1.37-10.

Zeng D., Chen H., Lusch R., Li S. H., 2010. Social media analytics and intelligence. IEEE Intelligent Systems 25(6): 13-16. DOI 10.1109/MIS.2010.151.

Zhang Z., Ye Q., Law R., Li Y., 2010. The impact of e-wordof-mouth on the online popularity of restaurants: A comparison of consumer reviews and editor reviews. International Journal of Hospitality Management 29(4): 694-700. DOI 10.1016/j.ijhm.2010.02.002.

Zhou L., Ye S., Pearce P.L., Wu M.Y., 2014. Refreshing hotel satisfaction studies by reconfiguring customer review data. International Journal of Hospitality Management 38: 1-10. DOI 10.1016/j.ijhm.2013.12.004.

Ziegler J.A., Silberg J.N., Araujo G., Labaja J., Ponzo A., Rollins R., Dearden P., 2018. A guilty pleasure: Tourist perspectives on the ethics of feeding whale sharks in Oslob, Philippines. Tourism Management 68: 264-274. DOI 10.1016/j.tourman.2018.04.001. 